\title{
Ultrastructural and cytochemical study of the bovine corpus luteum
}

\author{
Dilys M. Parry, D. L. Willcox and G. D. Thorburn* \\ Nuffield Department of Obstetrics and Gynaecology, John Radcliffe Hospital, Headington, \\ Oxford OX3 9DU, U.K.
}

\begin{abstract}
Summary. The large luteal cells comprise the bulk of the bovine corpus luteum during the most active secretory period of the oestrous cycle. At least 3 types of granules were present in mid-luteal cells: microperoxisomes, primary lysosomes and secretory granules. Only the last appear to be exocytosed. The concentration of these secretory granules in the luteal cytoplasm correlated with the reported profile of progesterone secretion by these cells throughout the cycle. Changes in the cytoplasmic proportions of the other subcellular organelles were consistent with the mobilization of steroid precursors stored in lipid droplets, synthesis of increased amounts of progesterone and protein, and the packaging of these products into discrete secretory granules.
\end{abstract}

\section{Introduction}

The corpus luteum is a suitable organ for correlating structure with endocrine function since it undergoes a series of defined structural and secretory phases within a short life-span. The histology of the bovine ovary has been described by various authors (McNutt, 1926; Hofliger, 1948; Rajakoski, 1960) and some histochemical reactions have been reported (Moss, Wrenn \& Sykes, 1954; Lobel \& Levy, 1968) but little morphological information is available at the ultrastructural level (Priedkalns \& Weber, 1968; Gemmell \& Stacy, 1979). Progesterone is the principal steroidogenic product, together with small amounts of 20 $\beta$-hydroxy-4-pregnen-3-one and pregnenolone (Mason, Marsh \& Savard, 1962).

Densely staining granules $(0.2-0.4 \mu \mathrm{m}$ in diameter) have been observed in a range of steroid-secreting cells (Christensen \& Gillim, 1969), although their function is presently unknown. Cavazos et al. (1969) stated that the electron-dense granules of the pig corpus luteum were lysosomes whilst Belt, Cavazos, Anderson \& Kraeling (1970) suggested that the granules stored relaxin. Gemmell, Stacy \& Thorburn $(1974,1976)$ have proposed that in the luteal cells of non-pregnant sheep progesterone is packaged into granules and secreted from the cell via exocytosis of these granules. Recent in-vitro experiments are also consistent with an exocytotic mode of steroid hormone secretion in the sheep (Sawyer, Abel, McClellan, Schmitz \& Niswender, 1979). Sub-cellular fractionation of the bovine corpus luteum showed that progesterone could be sedimented by centrifugation at moderate forces of gravity and was associated with the presence of densely staining granules (Quirk, Willcox, Parry \& Thorburn, 1979).

We conducted a morphological examination of the luteal cells of the cow in conjunction with the fractionation studies reported by Quirk et al. (1979). Our objective was to determine if the bovine luteal cell contained densely staining granules analogous to those in the sheep.

* Present address: Department of Physiology, University of Queensland, Brisbane, Australia. 
Cytochemical staining techniques were used to distinguish microperoxisomes and lysosomes from other densely staining bodies. A morphometric analysis of the cytoplasm of luteal cells was undertaken to correlate changes in the proportions of the subcellular organelles throughout the oestrous cycle with known endocrine events.

\section{Materials and Methods}

A corpus luteum was obtained within 5 min of death from Friesian cows on known days of the oestrous cycle from the Agricultural Research Council Laboratories at Compton, Berkshire. Representative tissue pieces $\left(\leqslant 1 \mathrm{~mm}^{3}\right)$ were immersion fixed in $3 \%(\mathrm{v} / \mathrm{v})$ glutaraldehyde in 0.1 M-cacodylate buffer, $\mathrm{pH} 7 \cdot 4$, for $2 \mathrm{~h}$ on ice. After overnight washing in buffer, the tissue was post-fixed for $30 \mathrm{~min}$ in cacodylate-buffered $1 \%(\mathrm{w} / \mathrm{v})$ osmium tetroxide, dehydrated through an ethanol series, immersed in propylene oxide and embedded in Araldite. Sections were stained in methanolic uranyl acetate and lead citrate (Reynolds, 1963) and viewed in a Philips 301 electron microscope. For the cytochemical studies, the fresh corpora lutea were sliced into approximately $20-\mu \mathrm{m}$ sections using a hand tissue-slicer and fixed for $3 \mathrm{~h}$ in $3 \%(\mathrm{v} / \mathrm{v})$ glutaraldehyde buffer, $\mathrm{pH}$ $7 \cdot 4$, containing $7 \%(\mathrm{w} / \mathrm{v})$ sucrose. For the determination of peroxidase activity, tissue sections were incubated in an alkaline diaminobenzidine (DAB) medium (pH 9.0) for $2 \mathrm{~h}$ at $37^{\circ} \mathrm{C}$ (Novikoff \& Goldfischer, 1969). For acid phosphatase cytochemistry, 20- $\mu \mathrm{m}$ sections were fixed for $30 \mathrm{~min}$ in $1 \%(\mathrm{v} / \mathrm{v})$ glutaraldehyde in $0.1 \mathrm{M}$-cacodylate buffer containing $7 \%(\mathrm{w} / \mathrm{v})$ sucrose and the enzymic activity was detected by the deposition of lead phosphate according to the method of Barka \& Anderson described in Essner (1973).

\section{Morphometry}

Micrographs of tissue sections were obtained randomly by photographing the bottom two corners of every grid square. The proportion of luteal cells in single corpora lutea obtained on Days $6,13,15,17$ and 20 of the oestrous cycle was determined by using a random-point counting technique. This analysis provided the volume fraction of each cell type in the corpus luteum. The area fractions of various subcellular organelles were similarly estimated at higher magnification by the technique of Glagoleff (1933), as described in Williams (1977). In addition, selected sections stained for peroxidase activity were subjected to morphometric analysis.

\section{Results}

The large granulosa lutein cells were the most prominent feature of the mid-luteal corpus luteum, which also contained some small luteal cells interspersed with a few fibroblasts and loose connective tissue. As we did not observe morphological differences between large and small luteal cells as previously described (Priedkalns \& Weber, 1968), they were regarded as part of the same population. The tissue was highly vascularized so that the large luteal cells $(25-40 \mu \mathrm{m}$ in diameter) were always close to capillaries. Their outer membranes were highly convoluted, providing the cell with a large surface area. The nuclei were similar in appearance to those of the luteal cells of other species, being large, round and approximately $10 \mu \mathrm{m}$ in diameter. Mitochondria were abundant and dispersed throughout the cytoplasm (Pl. 1, Fig. 1); they were generally large and pleomorphic, and contained tubular cristae, a characteristic feature of other steroid-secreting cells (Christensen \& Gillim, 1969) (Pl. 2, Fig. 2).

Agranular endoplasmic reticulum was the most prominent feature of the cytoplasm. It was

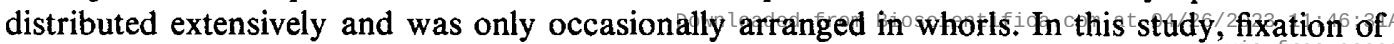




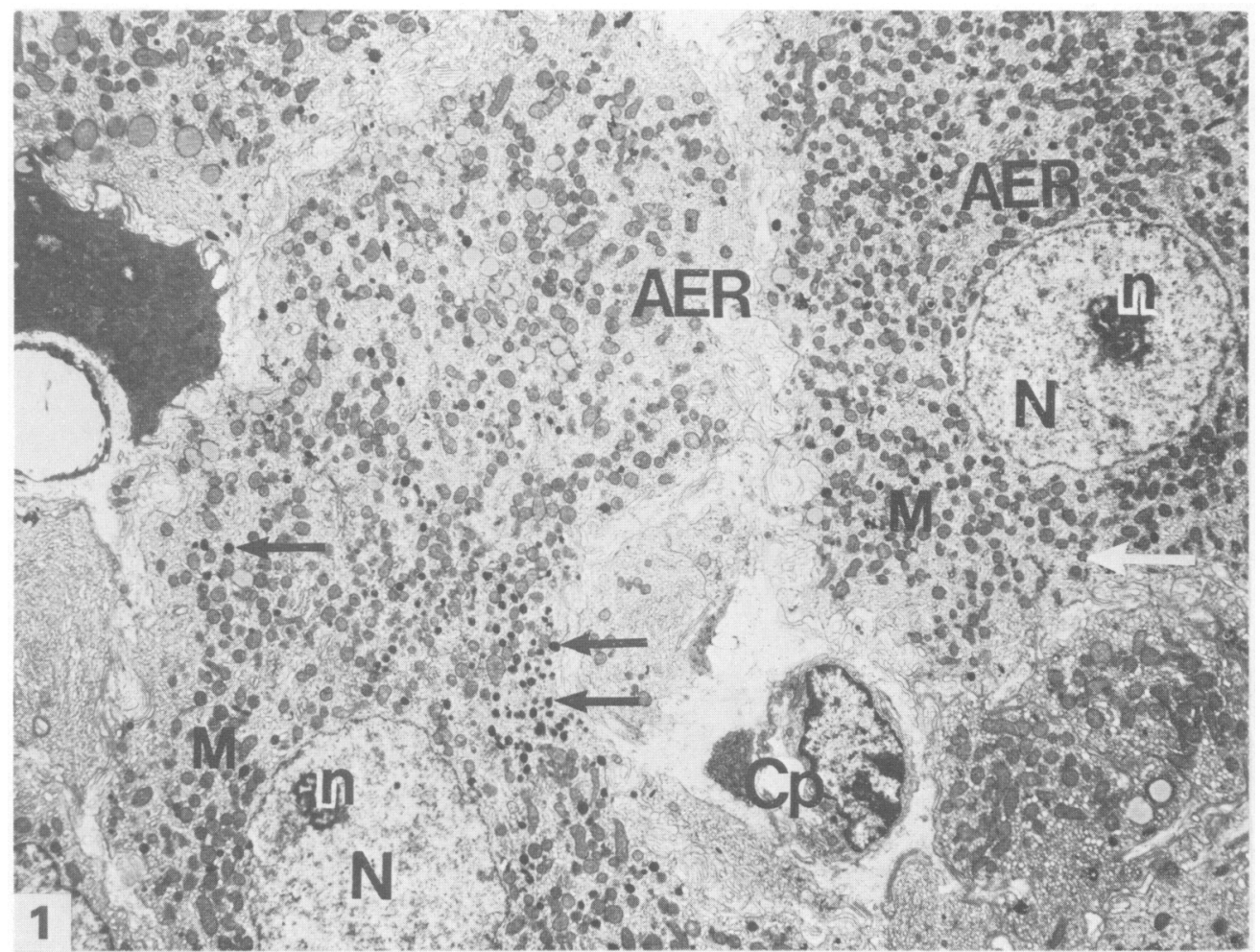

Fig. 1. A section of corpus luteum obtained from a cow on Day 13 of the oestrous cycle. Luteal cells are adjacent to a capillary $(\mathrm{Cp})$. They contain large nuclei $(\mathrm{N})$ with prominent nucleoli $(\mathrm{n})$; their cytoplasm contains numerous mitochondria (M), abundant agranular endoplasmic reticulum (AER), and patches of electron-dense granules (arrows) which are most abundant near the convoluted cell margins. $\times 3400$. 


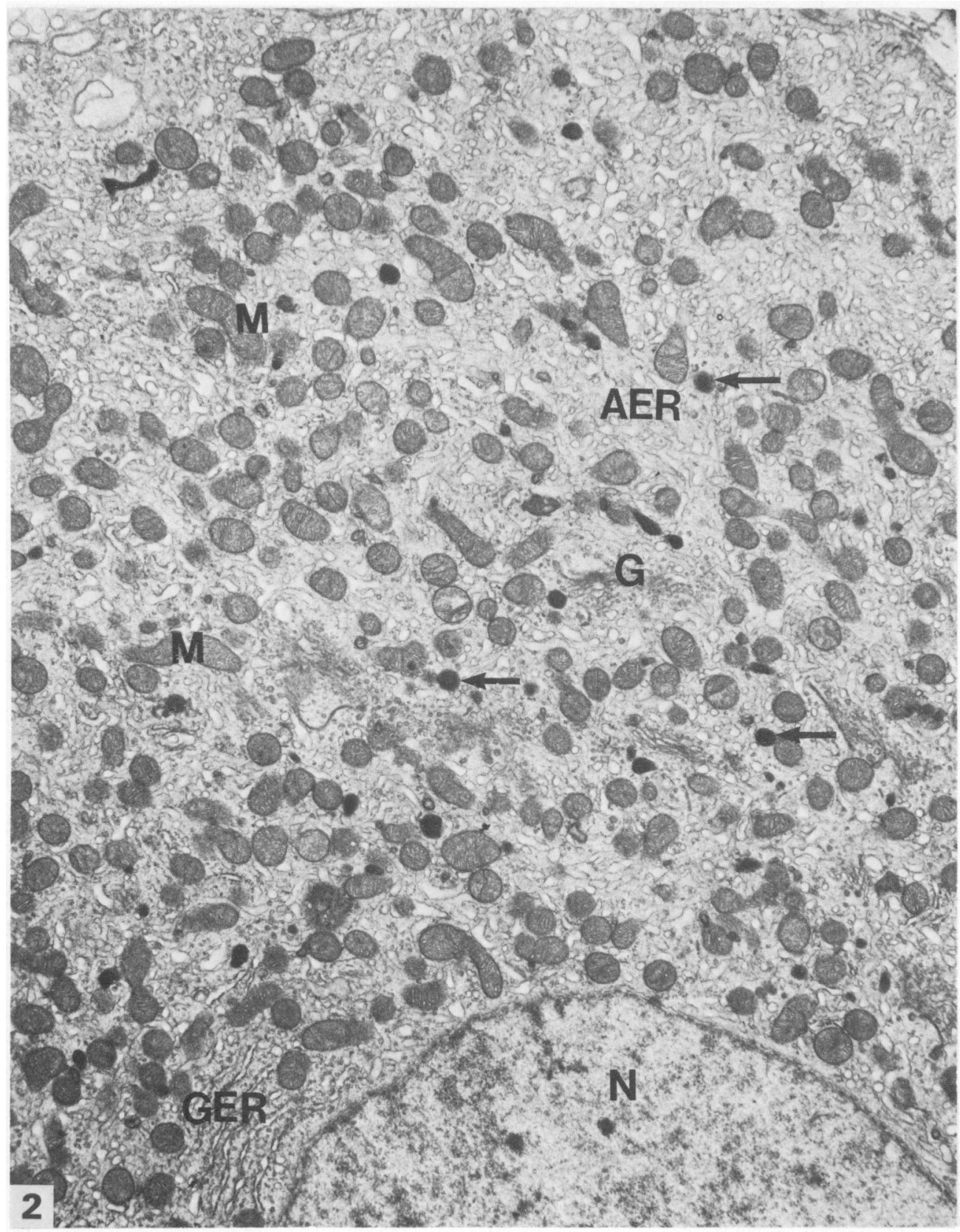

Fig. 2. A portion of a bovine luteal cell obtained at Day 13 of the oestrous cycle. Mitochondria (M) containing tubular cristae are dispersed throughout the cytoplasm. Golgi complexes (G) and granular endoplasmic reticulum (GER) occur discretely amongst the extensive and vesiculated agranular endoplasmic reticulum (AER). Densely staining granules (arrows) occur widely and some are found close to Golgi membranes. $\mathrm{N}=$ nucleus. $\times 10900$. 

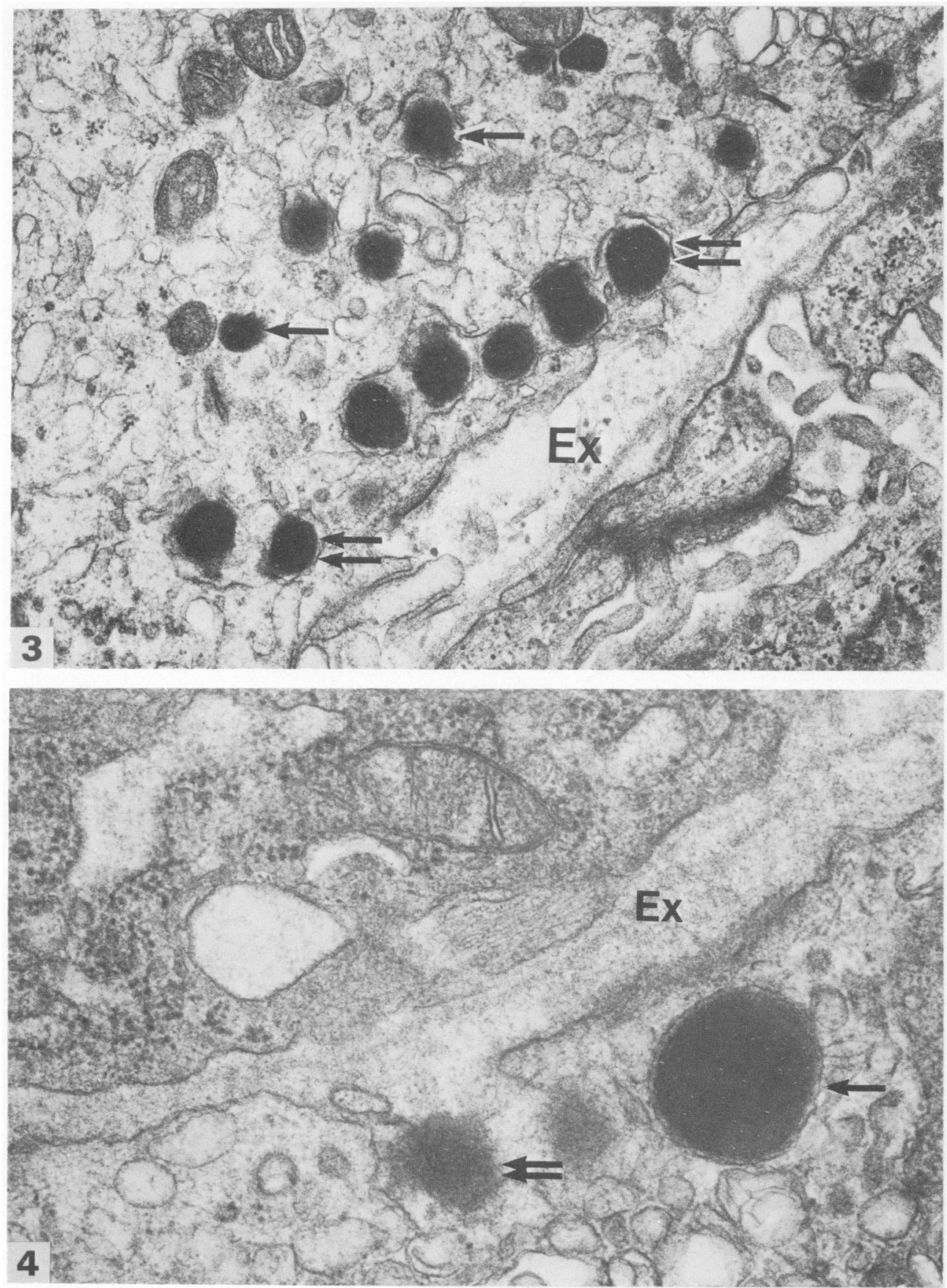

Fig. 3. Densely staining granules (single arrows) at the periphery of a large luteal cell obtained from a cow on Day 13 of the oestrous cycle. Some of the granules are located in the extracellular space (Ex), suggesting that they have undergone secretion (double arrows). $\times 30000$.

Fig. 4. Secretion of the granules (single arrows) is accompanied by loss of their surrounding membranes, followed by gradual diminution of their contents (double arrow). $\times 55000$. 

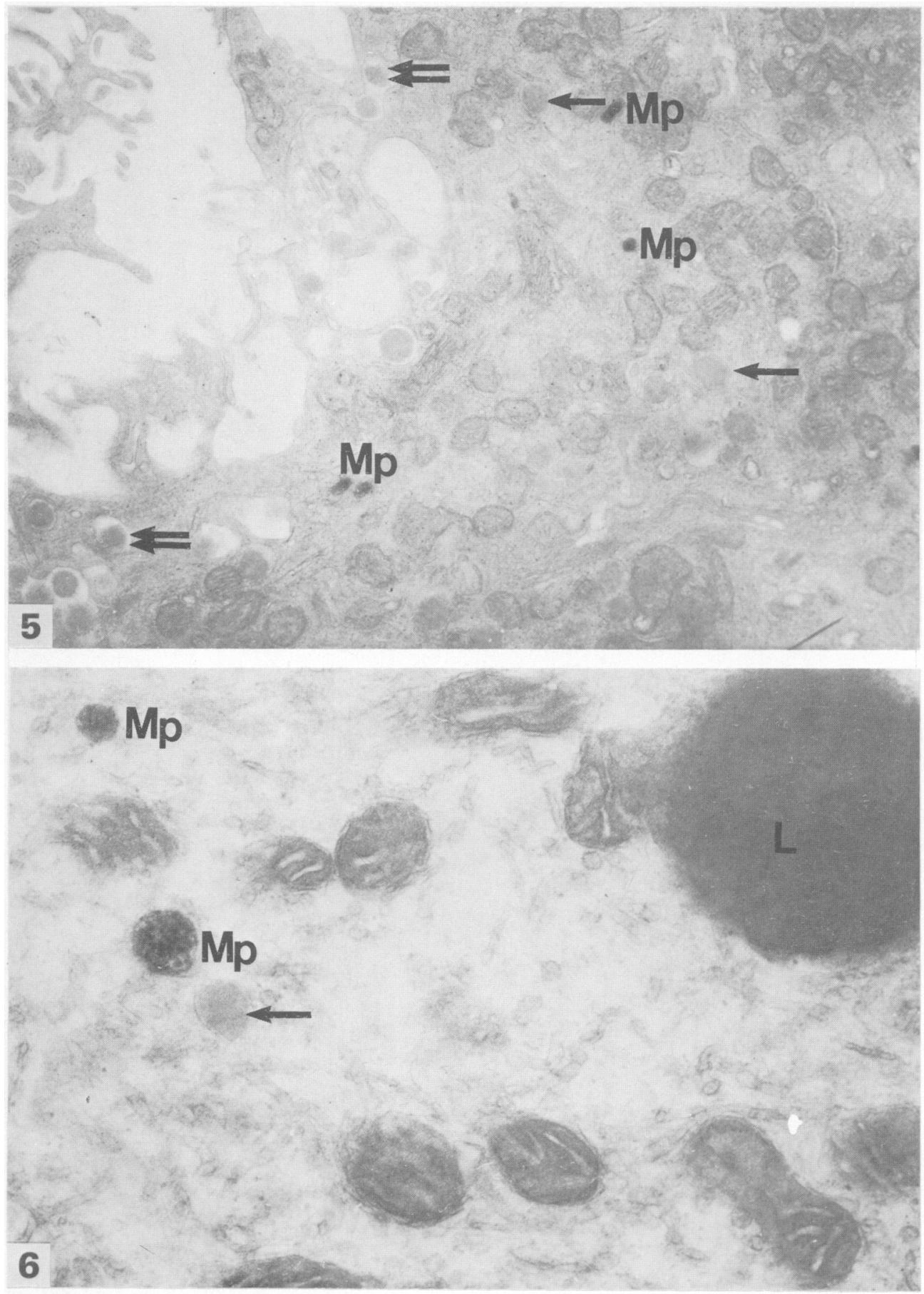

Figs 5 and 6. Portion of a luteal cell, from a cow on Day 13 of the oestrous cycle, incubated with alkaline diaminobenzidine to demonstrate microperoxisomes. The sections are not counterstained and the dense osmiophilic reaction product can be seen over microperoxisomes (Mp). Figure 5 shows many unstained granules (single arrows) some of which have been secreted from the cell (double arrows). DAB staining is always intracellular. $\times 16600$. In Fig. 6 a large lipid droplet $(\mathrm{L})$ is also present and an unstained secretory granule (arrow). $\times 33750$. 
tissue pieces by immersion in glutaraldehyde yielded micrographs in which this reticulum appeared as a collection of swollen membrane vesicles, whereas in the living cell it is thought to consist of a system of branching and interconnected tubules (Enders, 1962; Christensen \& Gillim, 1969). Granular endoplasmic reticulum occurred only in small amounts as discrete patches scattered throughout the cytoplasm, which also contained numerous free ribosomes and/or polysomes (Pl. 2, Fig. 2).

Golgi complexes were extensive and numerous in the cytoplasm of the large luteal cells, and consisted of stacks of closely packed cisternae and collections of vesicles. Small, membranebound vesicles, which were often electron-dense, were commonly observed in the region of the Golgi complex, suggesting that they had been 'budded off' from this organelle (Pl. 2, Fig. 2). Microtubules and microfilaments were occasionally observed but were not prominent features of the large bovine luteal cell, in contrast to the same cells of women (Crisp, Dessouky, Dessouky \& Denys, 1970) and bitches (Crisp, Denys \& Channing, 1972).

Electron-dense secretory granules were noticeable in the cytoplasm of the large cells of the mid-cycle bovine corpus luteum (Pl. 2, Fig. 2). They were $0.2-0.4 \mu \mathrm{m}$ in diameter, compared to $0.2 \mu \mathrm{m}$ diameter in sheep (Gemmell et al., 1974). A single membrane enclosed the electron-dense contents, which were uniformly opaque at high magnification. The granules were usually spherical, although some pleomorphism was observed, such as a 'dumb bell' configuration. They were distributed in clusters throughout the cytoplasm, especially in the vicinity of the Golgi complexes, and were also often found near the edge of the cell. These electron-dense granules were observed in the extracellular space, which suggested that they had been secreted. Their extrusion from the cell was accompanied by fusion of their membrane with the cell membrane. Once outside the cell, the contents of the granules appeared to disperse: this process was accompanied by a gradual diminution in the granule electron-density (Pl. 3, Figs 3 and 4).

Microperoxisomes were indistinguishable from the secretory granules on morphological grounds. Similarly, primary lysosomes (if present) were not identifiable by morphological examination alone, but secondary lysosomes (containing inclusion bodies) were sometimes seen in the cytoplasm. Microperoxisomes were identified by their peroxidase staining and were distributed discretely throughout the cytoplasm (Pl. 4, Fig. 5). In general, they occurred in those areas of the cytoplasm that contained the greatest number of lipid droplets (Pl. 4, Fig. 6). The diameter of the microperoxisomes ranged from 0.15 to $0.25 \mu \mathrm{m}$. The larger osmiophilic granules $(0.2-0.4 \mu \mathrm{m}$ in diameter) did not stain cytochemically for peroxidase activity and were morphologically classified as the putative secretory granules. Deposits of diaminobenzidine were always intracellular.

The putative secretory granules did not stain for acid phosphatase either in the luteal cell cytoplasm or in the extracellular space. These results were confirmed in tissue sections of bovine corpora lutea obtained on Days 6, 12,15 and 20 of the oestrous cycle.

Lipid droplets were present in some of the cells. Their contents were uniformly opaque and in general their concentration varied inversely to the numbers of electron-dense granules present. In cells containing large numbers of lipid droplets, evidence for exocytosis of electron-dense granules was rare.

\section{Morphometry}

Low magnification micrographs were analysed to obtain the proportions of luteal cells (Table 1). One corpus luteum was examined for each stage of the cycle. The luteal cells comprised about $50 \%$ of the area fraction of the corpus luteum on Day 6, at which time the secretion rate of progesterone was still rising (Herriman, Harwood, Mallison \& Heitzman, 1979). At Day 12, progesterone secretion was maximal and the large luteal cells reached their greatest area fraction of around $70 \%$. At Day 20, when the corpus luteum ceased secreting 
significant amounts of progesterone and degenerative processes predominated, the proportion of large luteal cells decreased to represent about $60 \%$ of the corpus luteum.

Table 1. The proportions (see 'Materials and Methods') of luteal cells in the bovine corpus luteum throughout the oestrous cycle

\begin{tabular}{lcrrrrr}
\hline & \multicolumn{5}{c}{ Day of oestrous cycle } \\
\cline { 2 - 6 } & & \multicolumn{1}{c}{6} & 13 & 15 & 17 & 20 \\
\hline Luteal cells & No. & 1045 & 2990 & 1663 & 1629 & 1578 \\
& $\%$ & 51.2 & 70.9 & 71.6 & 74.2 & 59.0 \\
Blood vessels + RBC & No. & 249 & 308 & 173 & 156 & 174 \\
& $\%$ & 12.2 & $7 \cdot 3$ & 7.5 & $7 \cdot 1$ & 6.5 \\
Extracellular space & No. & 606 & 735 & 349 & 322 & 616 \\
& $\%$ & 29.7 & 17.4 & 15.0 & 14.7 & 23.1 \\
Other tissue & No. & 142 & 183 & 139 & 89 & 305 \\
& $\%$ & 7.0 & 4.3 & 6.0 & 4.1 & 11.4 \\
No. of random points & & 2042 & 4216 & 2324 & 2196 & 2673 \\
No. of fields & & 17 & 36 & 19 & 20 & 24 \\
\hline
\end{tabular}

The final magnification was $\times 4130$.

Table 2. The proportions (see 'Materials and Methods') of subcellular components in the cytoplasm of the large cells of the bovine corpus luteum at different stages of the oestrous cycle

\begin{tabular}{|c|c|c|c|c|c|c|}
\hline & & \multicolumn{5}{|c|}{ Day of oestrous cycle } \\
\hline & & 6 & 13 & 15 & 17 & 20 \\
\hline Mitochondria & $\begin{array}{l}\text { No. } \\
\%\end{array}$ & $\begin{array}{r}346 \\
15 \cdot 6\end{array}$ & $\begin{array}{r}570 \\
25 \cdot 6\end{array}$ & $\begin{array}{r}678 \\
31 \cdot 0\end{array}$ & $\begin{array}{r}628 \\
25 \cdot 8\end{array}$ & $\begin{array}{r}669 \\
34 \cdot 0\end{array}$ \\
\hline Lipid droplets & $\begin{array}{l}\text { No. } \\
\%\end{array}$ & $\begin{array}{l}204 \\
9 \cdot 2\end{array}$ & $\begin{array}{r}60 \\
3 \cdot 2\end{array}$ & $\begin{array}{r}36 \\
1 \cdot 6\end{array}$ & $\begin{array}{l}121 \\
5 \cdot 0\end{array}$ & $\begin{array}{r}342 \\
17 \cdot 4\end{array}$ \\
\hline $\begin{array}{l}\text { Agranular endoplasmic } \\
\text { reticulum + groundplasm }\end{array}$ & $\begin{array}{l}\text { No. } \\
\%\end{array}$ & $\begin{array}{l}1317 \\
59 \cdot 4\end{array}$ & $\begin{array}{r}1215 \\
54 \cdot 5\end{array}$ & $\begin{array}{r}937 \\
42 \cdot 8\end{array}$ & $\begin{array}{l}1033 \\
42 \cdot 4\end{array}$ & $\begin{array}{r}590 \\
30.0\end{array}$ \\
\hline $\begin{array}{l}\text { Granular endoplasmic } \\
\text { reticulum + ribosomes }\end{array}$ & $\begin{array}{l}\text { No. } \\
\%\end{array}$ & $\begin{array}{r}6 \\
0 \cdot 3\end{array}$ & $\begin{array}{r}164 \\
7 \cdot 4\end{array}$ & $\begin{array}{l}167 \\
7 \cdot 6\end{array}$ & $\begin{array}{r}297 \\
12 \cdot 2\end{array}$ & $\begin{array}{r}229 \\
11 \cdot 7\end{array}$ \\
\hline Densely staining bodies & $\begin{array}{l}\text { No. } \\
\%\end{array}$ & $\begin{array}{r}55 \\
2 \cdot 5\end{array}$ & $\begin{array}{r}69 \\
3 \cdot 1\end{array}$ & $\begin{array}{r}64 \\
2 \cdot 9\end{array}$ & $\begin{array}{r}136 \\
5 \cdot 6\end{array}$ & $\begin{array}{r}37 \\
1.9\end{array}$ \\
\hline Golgi vesicles & $\begin{array}{l}\text { No. } \\
\%\end{array}$ & $\begin{array}{r}19 \\
0.9\end{array}$ & $\begin{array}{r}72 \\
3 \cdot 2\end{array}$ & $\begin{array}{r}111 \\
5 \cdot 1\end{array}$ & $\begin{array}{r}96 \\
3.9\end{array}$ & $\begin{array}{r}32 \\
1.6\end{array}$ \\
\hline Golgi cisternae & $\begin{array}{l}\text { No. } \\
\%\end{array}$ & $\begin{array}{c}40 \\
1 \cdot 8\end{array}$ & $\begin{array}{l}42 \\
1.9\end{array}$ & $\begin{array}{r}56 \\
2 \cdot 6\end{array}$ & $\begin{array}{c}59 \\
2 \cdot 4\end{array}$ & $\begin{array}{l}18 \\
0.9\end{array}$ \\
\hline Lysosomes & $\begin{array}{l}\text { No. } \\
\%\end{array}$ & $\begin{array}{c}2 \\
0.09\end{array}$ & $\begin{array}{c}1 \\
0.05\end{array}$ & $\begin{array}{c}7 \\
0.03\end{array}$ & $\begin{array}{r}30 \\
1.2\end{array}$ & $\begin{array}{r}37 \\
1.9\end{array}$ \\
\hline Open vesicles & $\begin{array}{l}\text { No. } \\
\%\end{array}$ & $\begin{array}{c}209 \\
9.5\end{array}$ & $\begin{array}{r}29 \\
1 \cdot 3\end{array}$ & $\begin{array}{l}124 \\
5 \cdot 7\end{array}$ & $\begin{array}{r}11 \\
0.5\end{array}$ & $\begin{array}{r}7 \\
0.4\end{array}$ \\
\hline Crystalline bodies & $\begin{array}{l}\text { No. } \\
\%\end{array}$ & $\begin{array}{c}2 \\
0.09\end{array}$ & $\begin{array}{c}2 \\
0.09\end{array}$ & $\begin{array}{c}3 \\
0 \cdot 14\end{array}$ & $\begin{array}{l}0 \\
0\end{array}$ & $\begin{array}{l}0 \\
0\end{array}$ \\
\hline Unassigned & $\begin{array}{l}\text { No. } \\
\%\end{array}$ & $\begin{array}{r}12 \\
0.5\end{array}$ & $\begin{array}{r}4 \\
0.2\end{array}$ & $\begin{array}{r}6 \\
0 \cdot 3\end{array}$ & $\begin{array}{r}23 \\
0.9\end{array}$ & $\begin{array}{c}5 \\
0.25\end{array}$ \\
\hline No. of random points & & $\begin{array}{r}2212 \\
21\end{array}$ & $\begin{array}{r}2228 \\
22\end{array}$ & $\begin{array}{r}2189 \\
22\end{array}$ & $\begin{array}{r}2434 \\
22 \cdot 5\end{array}$ & $\begin{array}{r}1966 \\
22\end{array}$ \\
\hline
\end{tabular}


Morphometric analysis of the cytoplasm of large luteal cells on 5 different days of the oestrous cycle showed that the proportion of mitochondria rose throughout the cycle (Table 2). Lipid droplet numbers fell as the rate of secretion of progesterone by the luteal cells increased but rose by Day 20 when progesterone secretion had ceased. The protein-synthesizing compartment, consisting of granular endoplasmic reticulum plus polysomes and/or ribosomes, increased steadily from Day 6 to Day 17 of the cycle. The Golgi apparatus (cisternae plus vesicles) constituted 5-7\% of the luteal cell cytoplasm from Days 6 to 17, but by Day 20 its contribution had declined to approximately $1 \%$ of the cytoplasm. Until Day 20, agranular endoplasmic reticulum and groundplasm were the most abundant cytoplasmic components, as expected in a steroidogenically active tissue (Christensen \& Gillim, 1969).

The population of densely staining bodies included not only the putative progesterone secretory granules but also microperoxisomes and any other electron-dense, membrane-bound body (including primary lysosomes) of $0.2-0.4 \mu \mathrm{m}$ diameter. The general class of densely staining bodies varied with the stage of the oestrous cycle. The concentration of microperoxisomes doubled between Days 6 and 15 to constitute approximately one-third of the total population of electron-dense granules (Table 3).

Table 3. The cytoplasmic proportions of microperoxisomes in the large luteal cells at different times of the oestrous cycle

\begin{tabular}{lccc}
\hline & \multicolumn{3}{c}{ Day of oestrous cycle } \\
\cline { 2 - 4 } & 6 & 15 & 17 \\
\hline No. of microperoxisomes & 42 & 76 & 72 \\
No. of other densely staining bodies & 216 & 156 & 148 \\
\% of microperoxisomes & $16 \cdot 3$ & $32 \cdot 8$ & $32 \cdot 7$ \\
No. of fields examined & 14 & 13 & 14 \\
\hline
\end{tabular}

The final magnification was $\times 14030$.

\section{Discussion}

The morphological features of the large luteal cells of the cow were comparable to those described for steroid-secreting cells generally and for the luteal cells in particular of other mammals (Fawcett, Long \& Jones, 1969; Christensen \& Gillim, 1969; Enders, 1973). Although bovine luteal cells contained abundant agranular endoplasmic reticulum, it was only rarely in whorls, and even then the whorls were not as extensive as those observed in the luteal cells of other animals (Bjersing, 1967; Crisp et al., 1970; Crombie, Burton \& Ackland, 1971).

Previous cytochemical studies of steroidogenic cells have concentrated on the role of lysosomes in steroidogenesis (see Elfont, Roszka \& Dimino, 1977) or luteal cell regression (see Bjersing, Hay, Moor, Short \& Deane, 1970; Gemmell et al., 1976) and on the distribution of microperoxisomes among different cell types. Microperoxisomes have been found in the cells of the adrenal cortex (Beard, 1972), the testicular interstitium (Reddy \& Svoboda, 1972) and the primate corpus luteum (Gulyas \& Yuan, 1975). Gulyas \& Yuan (1975) observed three distinct populations of granules in luteal cells of the pregnant rhesus monkey: large granules of irregular outline, medium-sized granules $(0.5-1.2 \mu \mathrm{m}$ diameter), and small granules $(0.1-0.45 \mu \mathrm{m}$ diameter) which they identified as microperoxisomes by cytochemistry. They were unable to suggest a function for the largest granule; they could have been lysosomes or analogous to the relaxin storage granules in the luteal cells of pregnant pigs (Cavazos et al., 1969; Belt, Anderson, Cavazos \& Melampy, 1971) and rats (Long, 1978). The medium-sized granules were not microperoxisomes (Gulyas \& Yuan, 1975), but were morphologically very similar to the secretory granules found in the luteal cells of sheep (Gemmell et al., 1974) and cows (present 
study). The role of microperoxisomes in the metabolism of luteal cells is unknown. The fact that they appear to be derived from the agranular endoplasmic reticulum and that they are found in association with (or at least adjacent to) lipid droplets in the cytoplasm of a number of different cells (Leuenberger \& Novikoff, 1973; Novikoff \& Novikoff, 1973; Novikoff, Novikoff, Quintana \& Davis, 1973) has led to the suggestion that microperoxisomes are involved in steroidogenesis in luteal cells (Gulyas \& Yuan, 1975).

The localization of relaxin antibodies over granules in the pregnant sow has been achieved by the immunoperoxidase technique (Kendall, Plopper \& Bryant-Greenwood, 1978). The human corpus luteum is a rich source of relaxin during pregnancy also, and its secretion correlates well with that of luteal progesterone at mid-pregnancy and term (Weiss et al., 1977). However, relaxin was undetectable in the corpora lutea of non-pregnant women (O'Byrne et al., 1978) and during the oestrous cycle of sheep maximal circulating concentrations of progesterone and relaxin did not coincide (Chamley, Stelmasiak \& Bryant, 1975). Thus, the intragranular sequestration of relaxin may be a phenomenon restricted to pregnancy, especially as Cavazos et al. (1969) and Belt et al. (1971) did not obtain evidence for the secretion of relaxin granules from the luteal cells of non-pregnant sows.

In sections of bovine luteal cells stained for acid phosphatase activity, membrane-bound granules other than lysosomes were also adjacent to the cisternae of the Golgi apparatus, suggesting that they had been formed by this organelle. These granules were free of product resulting from acid phosphatase activity. Such an observation has also been made in the sheep (McClellan, Abel \& Niswender, 1977). These findings, together with the observation that not all of the Golgi cisternae were acid phosphatase-positive, suggest that the organelle has functions additional to the packaging of lysosomes and correlates with the observation that Golgi membranes were prominent in luteal cells of the mid-cycle cow, when lysosomes were not numerous. Elfont et al. (1977) have observed acid phosphatase staining around the rim of lipid bodies in gonadotrophin-treated, immature rats and suggested that the lysosomal system is involved in making substrate available for steroid synthesis and/or facilitating steroid secretion. However, the possibility that microperoxisomes are also involved in steroidogenesis (e.g. mobilization of cholesterol from lipid droplets) in the cow cannot be excluded. They comprised at least 4-fold more of the luteal cell cytoplasm than lysosomes during the active luteal phase and were commonly observed adjacent to lipid droplets, whereas the lysosomes present at these times appeared to occur randomly throughout the cytoplasm. Acid phosphatase staining around the rim of lipid droplets was only observed during luteal regression in the cow, by which time secondary lysosomes were common and secretion of progesterone had practically ceased.

It is possible that small numbers of primary lysosomes are required during the luteal phase to degrade unwanted compounds including gonadotrophin or even steroid receptors. Polypeptide hormones such as insulin, prolactin and growth hormone have been localized within cells using immunofluorescent techniques (Kolata, 1978) and specific binding of LH to lysosomes has been demonstrated in ovine luteal cells (Chen et al., 1977). Prostaglandin and gonadotrophin receptors have also been found associated with lysosomal membranes in bovine luteal cells (Mitra \& Rao, 1978).

Increased concentrations of mitochondria in luteal cells at mid-cycle correlate with the expected requirement for greater amounts of cholesterol side-chain cleavage activity to accompany increased synthesis of progesterone. Lipid droplets contain cholesterol in the cow (Flint \& Armstrong, 1971) and cholesterol esters in other species (Fienberg \& Cohen, 1965). The concentration of lipid droplets in bovine luteal cytoplasm varied inversely with the rate of progesterone synthesis throughout the oestrous cycle, in agreement with their projected role as stores of steroid precursors (Deane, Hay, Moor, Rowson \& Short, 1966). Groundplasmagranular endoplasmic reticulum, whilst remaining the most abundant subcellular compartment of the luteal cytoplasm, nevertheless declined during the course of the oestrous cycle as the proportion of other organelles increased. The role of secondary lysosomes in luteal regression is 
well known (Deane et al., 1966; Dingle, Hay \& Moor, 1968; Bjersing et al., 1970; Gemmell et al., 1976; McClellen et al., 1977; Elfont et al., 1977). The first structural signs of luteolysis in the sheep were seen at Day 12 of the oestrous cycle when a decrease in the secretion of progesterone and concentration of densely staining granules coincided with the emergence within luteal cells of secondary lysosomes and autophagocytic bodies (Gemmell et al., 1976).

Secretory granules were present throughout the luteal phase of the bovine oestrous cycle. Although they comprised only $2-4 \%$ of the luteal cell cytoplasm, they are probably packaged and released rapidly so that few mature granules would be in the luteal cytoplasm at any time. The concentration of secretory granules was maximal on Day 17, at the onset of luteolysis. This is compatible with the finding that structural dislocation of the secretory process precedes the cessation of progesterone synthesis in the cow (Hansel, Concannon \& Lukawzewska, 1973). The numbers of secretory granules would then increase temporarily in the cytoplasm before being degraded by secondary lysosomes.

The presence of large nucleoli during the active secretory phase, together with patches of well developed granular endoplasmic reticulum and numerous ribosomes and/or polysomes scattered throughout the cytoplasm, suggests that protein synthesis is an important feature of luteal metabolism in the cow. Secretion of protein and steroid occurs in the adrenal and corpus luteum (Rubin, Sheid, McCauley \& Laychock, 1974; Laychock \& Rubin, 1974; Gemmell, Laychock \& Rubin, 1977; Abel, Verhage, McClellan \& Niswender, 1977). The bovine corpus luteum contains binding proteins for progesterone (Willcox, Jenkin, Quirk \& Thorburn, 1978; Willcox, 1979) which may be involved in intracellular synthesis and/or transport of the hormone. It is likely that the presence of a progesterone-binding protein in the secretory granules of the bovine corpus luteum renders the granules electron-dense.

We thank Miss Elaine Johnston for skilled technical assistance and Dr. S. Dixon and Dr R. Heitzmann at the A.R.C. Laboratories, Compton, for the material. D.L.W. is a Nuffield Dominions Trust Demonstrator.

\section{References}

Abel, J.H., Jr, Verhage, H.G., McClellan, M.C. \& Niswender, G.D. (1977) Synthesis and release of a secretory protein from lutein cells. J. Cell Biol. 75, $374 a$.

Beard, M.E. (1972) Identification of peroxisomes in the rat adrenal cortex. J. Histochem. Cytochem. 20, 173-179.

Belt, W.D., Cavazos, L.F., Anderson, L.L. \& Kraeling, R.R. (1970) Fine structure and progesterone levels in the corpus luteum of the pig during pregnancy and after hysterectomy. Biol. Reprod. 2, 98-113.

Belt, W.D., Anderson, L.L., Cavazos, L.F. \& Melampy, R.M. (1971) Cytoplasmic granules and relaxin levels in porcine corpora lutea. Endocrinology 89, $1-10$.

Bjersing, L. (1967) On the ultrastructure of the granulosa lutein cells in the porcine corpus luteum. With special reference to endoplasmic reticulum and steroid hormone synthesis. Z. Zellforsch. mikrosk. Anat. 82, $187-211$.

Bjersing, L., Hay, M.F., Moor, R.M., Short, R.V. \& Deane, H.W. (1970) Endocrine activity, histochemistry and ultrastructure of ovine corpora lutea I. Further observations on regression at the end of the oestrous cycle. Z. Zellforsch. mikrosk. Anat. 111, 439-457.
Cavazos, L.F., Anderson, L.L., Belt, W.D., Henricks, D.M., Kraeling, R.R. \& Melampy, R.M. (1969) Fine structure and progesterone levels in the corpus luteum of the pig during the oestrous cycle. Biol. Reprod. 1, 83-106.

Chamley, W.A., Stelmasiak, T. \& Bryant, G.D. (1975) Plasma relaxin immunoactivity during the oestrous cycle of the ewe. J. Reprod. Fert. 45, 455-461.

Chen, T.T., Abel, J.H., Jr, McClellan, M.C., Sawyer, H.R., Diekman, M.A. \& Niswender, G.D. (1977) Localization of gonadotrophic hormones in lysosomes of ovine luteal cells. Cytobiologie 14, 412-420.

Christensen, A.K. \& Gillim, S.W. (1969) The correlation of fine structure and function in steroid-secreting cells, with emphasis on those of the gonads. In The Gonads, pp. 415-488. Ed. K.W. McKerns. North Holland, Amsterdam.

Crisp, T.M., Dessouky, A., Dessouky, M.D. \& Denys, F.R. (1970) The fine structure of the human corpus luteum of early pregnancy and during the progestational phase of the menstrual cycle. $A m$. J. A nat. 127, 37-70.

Crisp, T.M., Denys, F.R. \& Channing, C.P. (1972) The fine structure of the canine corpus luteum of early pregnancy. Anat ${ }_{\mathrm{B}} \operatorname{Rec}_{\mathrm{C}} \mathbf{1 7 2}, 296$. 
Crombie, P.R., Burton, R.D. \& Ackland, N. (1971) The ultrastructure of the corpus luteum of the guinea pig. Z. Zellforsch. mikrosk. Anat. 115, 473-493.

Deane, H.W., Hay, M.F., Moor, R.M., Rowson, L.E.A. \& Short, R.V. (1966) The corpus luteum of the sheep: relationships between morphology and function during the oestrous cycle. Acta endocr., Copenh. 51, 594-609.

Dingle, J.T., Hay, M.F. \& Moor, R.M. (1968) Lysosomal function in the corpus luteum of the sheep. J. Endocr. 40, 325-336.

Elfont, E.A., Roszka, J.P. \& Dimino, M.J. (1977) Cytochemical studies of acid phosphatase in ovarian follicles: a suggested role for lysosomes in steroidogenesis. Biol. Reprod. 17, 787-795.

Enders, A.C. (1962) Observations on the fine structure of lutein cells. J. Cell Biol. 12, 101-113.

Enders, A.C. (1973) Cytology of the corpus luteum. Biol. Reprod. 8, 158-182.

Essner, E. (1973) Phosphatases. In Electron Microscopy of Enzymes. Principles and Methods, pp. 44-76. Ed. M. A. Hayat. van Nostrand Reinhold Co., New York.

Fawcett, D.W., Long, J.A. \& Jones, A.L. (1969) The ultrastructure of endocrine glands. Recent Prog. Horm. Res. 25, 315-380.

Fienberg, R. \& Cohen, R.B. (1965) A comparative histochemical study of the ovarian stromal lipid band, stromal thecal cell, and normal ovarian follicular apparatus. Am. J. Obstet. Gynec. 92, 958-969.

Flint, A.P.F. \& Armstrong, D. T. (1971) Intracellular localization of cholesterol side chain cleavage enzyme in corpora lutea of cow and rat. Nature, New Biol. 231, 60-61.

Gemmell, R.T. \& Stacy, B.D. (1979) Ultrastructural study of granules in the corpora lutea of several mammalian species. Am.J. Anat. 155, 1-14.

Gemmell, R.T., Stacy, B.D. \& Thorburn, G.D. (1974) Ultrastructural study of secretory granules in the corpus luteum of the sheep during the oestrous cycle. Biol. Reprod. 11, 447-462.

Gemmell, R.T., Stacy, B.D. \& Thorburn, G.D. (1976) Morphology of the regressing corpus luteum in the ewe. Biol. Reprod. 14, 270-279.

Gemmell, R.T., Laychock, S.G. \& Rubin, R.P. (1977) Uitrastructural and biochemical evidence for $a$ steroid-containing secretory organelle in the perfused cat adrenal gland. J. Cell Biol. 72, 209-215.

Gulyas, B.J. \& Yuan, L.C. (1975) Microperoxisomes in the late pregnancy corpus luteum of thesus monkeys (Macaca mulatta). J. Histochem. Cytochem. 23, 359-368.

Hansel, W., Concannon, P.W. \& Lukawzewska, J.H. (1973) Corpora lutea of large domestic animals. Biol. Reprod. 8, 222-245.

Herriman, I.D., Harwood, D.J., Mallison, C.B. \& Heitzman, R.J. (1979) Plasma concentrations of ovarian hormones during the oestrous cycle of the sheep and cow. J. Endocr. 81, 61-64.

Hofliger, H. (1948) Das Ovar des Rindes in den verschiedenen Lebensperioden unter besonderer
Berucksichtigung seiner funktionellen Feinstruktur. Acta anat., Suppl. 5, 3-195.

Kendall, J.Z., Plopper, C.G. \& Bryant-Greenwood, G.D. (1978) Ultrastructural immunoperoxidase demonstration of relaxin in corpora lutea from a pregnant sow. Biol. Reprod. 18, 94-98.

Kolata, G.B. (1978) Polypeptide hormones: what are they doing in cells? Science, N.Y. 201, 895-897.

Laychock, S.G. \& Rubin, R.P. (1974) Isolation of ACTH-induced protein from an adrenal perfusate. Steroids 24, 177-184.

Leuenberger, P.M. \& Novikoff, A.B. (1973) Microperoxisomes in the retina of pigmented and albino rodents. Expl Eye Res. 17, 399.

Lobel, B.L. \& Levy, E. (1968) Enzymic correlates of development, secretory function and regression of follicles and corpora lutea in the bovine ovary. Acta endocr., Copenh., Suppl. 132, 1-63.

Long, J.A. (1978) Corpus luteum of the rat-ultrastructural and cytochemical observations. Biol. Reprod. 8, 87-89.

Mason, N.R., Marsh, J.M. \& Savard, K. (1962) An action of gonadotrophin in vitro. J. biol. Chem. 237, 1801-1806.

McClellan, M.C., Abel, J.H., Jr \& Niswender, G.D. (1977) Function of lysosomes during luteal regression in normally cycling and $\mathbf{P G F}_{2}$-treated ewes. Biol. Reprod. 16, 499-512.

McNutt, G.W. (1926) The corpus luteum of the ox ovary in relation to the oestrous cycle. Iowa St. Coll. Publ. 25, Vet. Pract. Bull. 8, 79-107.

Mitra, S. \& Rao, Ch. V. (1978) Receptors for gonadotrophins and prostaglandins in lysosomes of bovine corpora lutea. Arch. Biochem. Biophys. 185, 126133.

Moss, S., Wrenn, T.R. \& Sykes, J.F. (1954) Some histological and histochemical observations of the bovine ovary during the oestrous cycle. Anat. Rec. $120,409-434$.

Novikoff, A.B. \& Goldfischer, S. (1969) Visualization of peroxisomes (microbodies) and mitochondria with diaminobenzidine. J. Histochem. Cytochem. 21, 963-966.

Novikoff, A.B. \& Novikoff, P.M. (1973) Microperoxisomes. J. Histochem. Cytochem. 21, 963-966.

Novikoff, A.B., Novikoff, P.M., Quintana, N. \& Davis, C. (1973) Studies on microperoxisomes IV. Interactions of microperoxisomes, endoplasmic reticulum and lipofuscin granules. J. Histochem. Cytochem. 21, 1010-1020.

O'Byrne, E.M., Flitcraft, J.F., Sawyer, W.K., Hochman, J., Weiss, G. \& Steinetz, B.G. (1978) Relaxin bioactivity and immunoactivity in human corpora lutea. Endocrinology 102, 1641-1644.

Priedkalns, J. \& Weber, A.F. (1968) Quantitative ultrastructural analysis of the follicular and luteal cells of the bovine ovary. Z. Zellforsch. mikrosk. Anat. 91, 574-585.

Quirk, S.J., Willcox, D.L., Parry, D.M. \& Thorburn, G.D. (1979) Subcellular location of progesterone in the bovine corpus luteum: a biochemical, morphological and cytochemical investigation. Biol. Reprod. $20,1133-1145$. 
Rajakoski, E. (1960) The ovarian follicular system in sexually mature heifers with special reference to seasonal, cyclical and left-right variations. Acta endocr., Copenh., Suppl. 52, 1-68.

Reddy, J.K. \& Svoboda, D. (1972) Microbodies (peroxisomes) identification in interstitial cells of the testis. $J$. Histochem. Cytochem. 20, 140-142.

Reynolds, E.S. (1963) The use of lead citrate at high pH as an electron opaque stain in electron microscopy. $J$. Cell Biol. 17, 208-213.

Rubin, R.P., Sheid, B., McCauley, R. \& Laychock, S.G. (1974) ACTH-induced protein release from the perfused cat adrenal gland: evidence for exocytosis? Endocrinology 95, 370-378.

Sawyer, H.R., Abel, J.H., Jr, McClellan, M.C., Schmitz, M. \& Niswender, G.D. (1979) Secretory granules and progesterone secretion by ovine corpora lutea in vitro. Endocrinology 104, 476-486.

Weiss, G., O'Byme, E.M., Hochman, J.A., Goldsmith, L.J., Rifkin, I. \& Steinetz, B.G. (1977) Secretion of progesterone and relaxin by the human corpus luteum at mid pregnancy and at term. Obstet. Gynec., N.Y. 50, 679-681.

Willcox, D.L. (1979) Hormone secretion in the corpus luteum. D.Phil. thesis, University of Oxford.

Willcox, D.L., Jenkin, G., Quirk, S.J. \& Thorburn, G.D. (1978) Progesterone binding protein in the bovine corpus luteum. J. Endocr. 80, 13P-14P.

Williams, M.A. (1977) Quantitative methods in biology. In Practical Methods in Electron Microscopy, ch. 6. Ed. A.N. Glauert. North-Holland, Amsterdam.

Received 31 January 1980 